\title{
Medieval forest dynamics in the Iberian Pyrenees: a comparison between low- and high-mountain areas
}

\author{
Valentí Rull ${ }^{1^{*}}$, Teresa Vegas-Vilarrúbia ${ }^{2}$ \\ ${ }^{1}$ Botanic Institute of Barcelona (IBB-CSIC), Pg. del Migdia s/n, 0838 Barcelona, Spain \\ ${ }^{2}$ Department of Evolutionary Biology, Ecology and Environmental Sciences, University of \\ Barcelona, Av. Diagonal 643, 08028 Barcelona, Spain
}

*Corresponding author. Email: vrull@csic.es

\begin{abstract}
This paper compares the Medieval (ca. 400-1500 CE) dynamics of forests from low-mountain (Montcortès; ca. $1000 \mathrm{~m}$ a.s.l.) and high-mountain (Sant Maurici; $1900 \mathrm{~m}$ a.s.l.) areas of the Iberian Pyrenees, both of which experienced similar climatic forcing but different anthropogenic pressures. The main aim is to identify forest changes over time and associate them with the corresponding climatic and anthropogenic drivers (or synergies among them) to test how different forests at different elevations respond to external forcings. This could be useful to evaluate the hypothesis of general Pyrenean deforestation during the Middle Ages leading to present-day landscapes and to improve the background for forest conservation. The study uses palynological analysis of lake sediments, historical documents and paleoecological reconstructions based on pollen-independent proxies. The two sites studied showed different forest trajectories. The Montcortès area was subjected to intense human pressure during regional deforestation up to a maximum of ca. $1000 \mathrm{CE}$. Further forest recovery took place until the end of the Middle Ages due to a change in forest management, including the abandonment of slash-and-burn practices. Climatic shifts indirectly influenced forest trends by regulating human migrations and the resulting shifts in the type and intensity of forest exploitation. The highland Sant Maurici forests exhibited a remarkably long-standing constancy and an exceptional resilience to climatic shifts, which were unable to affect forest extension and composition, and to local human pressure, from which they rapidly recovered. The Montcortès and Sant Maurici records did not follow the rule of an irreversible forest clearing during the Middle Ages leading to present-day landscapes. The present Montcortès landscape was shaped after a Medieval forest recovery, a new Modern-Age deforestation and a further forest recovery during the last centuries. The Sant Maurici forests remained apparently untouched since the Bronze Age and were never cleared during the Middle Ages. The relevance of these findings for forest conservation is briefly addressed, and the need for the development of more high-resolution studies on Pyrenean forest dynamics is highlighted.
\end{abstract}

Keywords: palynology, Pyrenees, Middle Ages, forest dynamics, forest management, resilience, deforestation, land use, climatic change 


\section{Introduction}

The European Middle Ages - also called the Medieval Period - correspond to the time period between the fall of the Occidental Roman Empire and the Renaissance, roughly encompassing the millennium between the $5^{\text {th }}$ and $15^{\text {th }}$ centuries. The beginning of the Middle Ages was not abrupt but transitional. When the Occidental Roman Empire disappeared, the so-called Barbarian cultures occupied its lands. The Migration Period has been defined across western Europe as the time interval between the end of the Roman Empire and the settlement of Barbarian peoples, lasting between approximately 380 CE and 570 CE [1]. Some regional chronological differences existed due to cultural disparities. In the southern, or Iberian, Pyrenees, the Middle Ages have been bracketed between approximately $420 \mathrm{CE}$ and $1490 \mathrm{CE}$ [2] and have been considered the epoch of major anthropogenic deforestation leading to present-day landscapes [3-5]. It has been suggested that the anthropization of the Iberian side of the Pyrenees was a gradual process, which began in the lowlands ( $<800 \mathrm{~m}$ elevation) during the Bronze Age and ended in the highlands (>1600 m elevation) during the Middle Ages [6]. Therefore, in the southern sector of the Pyreneam range, the Middle Ages are considered to be the time of full anthropization, as manifested in extensive and intensive forest clearing and landscape opening.

It is important to separate the concepts of human occupation and landscape anthropization. Human occupation refers to human presence in a given region, whereas landscape anthropization involves the extensive and irreversible landscape transformation introduced by human activities leading to the present landscape configuration [6]. Usually, human occupation is identified by archaeological evidence, and landscape anthropization is deduced from paleoecological evidence, mainly pollen analysis. In the case of the Iberian Pyrenees, archaeological evidence suggests that human occupation began during the Late Glacial-Early Holocene (19,000-8000 BCE). Neolithization started at 5600-3000 BCE, and high-mountain occupation was significantly enhanced between 3500 CE and 2500 BCE due to an increase in extensive pastoralism [7]. As mentioned above, landscape anthropization occurred much later, between the Bronze Age (ca. 1500 BCE) and the Middle Ages (ca. 1400 CE) [6], depending on the elevation. It is also worth mentioning that low- and mid-elevation areas that had been anthropized during the Bronze Age, the Iron Age and the Roman Period were further modified by recurrent human activities, culminating in the Middle Ages or later, when modern landscapes were shaped [8].

Forests were especially affected by human activities during Medieval times. According to the available palynological evidence, the most common disturbance was forest clearance (with or without the help of fire) to expand arable land and pastures. In the highlands, these activities were manifested in the lowering of the treeline and the significant expansion of alpine meadows, which favored the development of long-distance horizontal transhumance $[5,9]$. Forests were also used for wood and charcoal extraction, and in some instances, their taxonomic composition was intentionally changed to fulfil human needs. However, palynological studies used to derive these general Medieval trends are usually based on long sedimentary records embracing several millennia - even the whole Holocene and, occasionally, Late Pleistocene times - and lack the resolution needed to properly unravel the detailed forest dynamics during the Middle Ages. The lack of high-resolution records focused specifically on the Medieval dynamics of Pyrenean forests is a handicap to understand how these woodland communities were managed and how they were affected by climatic variability, as well as for eventual climatic-anthropogenic synergies. The potential effects of these natural and anthropogenic drivers on different forest communities situated at different elevations also remain unknown. 
This paper compares the high-resolution forest dynamics of Medieval forests from two localities (Lake Montcortès and Lake Sant Maurici) situated in different altitudinal zones (ca. $1000 \mathrm{~m}$ of vertical offset) within the same Pyrenean valley, corresponding to the Noguera Pallaresa River, draining to the south as part of the Ebro basin (Fig. 1). The complete record of both localities (Bronze Age to present) has recently been published elsewhere $[10,11]$, showing the general vegetational trends over time. Here, the emphasis is on Medieval forests, whose detailed dynamics have been reconstructed at subdecadal to bidecadal resolution and compared with the available paleoclimatic information and the cultural histoty. Lake Montcortès is situated ca. $1000 \mathrm{~m}$ elevation, which is the approximate boundary between the lowland and montane forest belts (Fig. 2). The varved sediments of this lake have provided subdecadal to decadal reconstructions of forest dynamics for the Middle Ages. Lake Sant Maurici is located ca. 1900 m elevation within the uppermost subalpine forest belt that defines the regional treeline. The Medieval part of this pollen record is of decadal to bidecadal resolution. Both lakes are in the historical Pallars region, with abundant and detailed historical documentation for comparison with paleoecological and climatic records $[12,13]$.

Comparing two records situated at the lowermost and uppermost forest belts within the same valley is important for climatic, ecological and cultural reasons. First, it is worth noting that in the Medieval Pallars, socioeconomical districts were organized into natural valleys, with a clear labor division between highlands and lower areas (Appendix 1). Therefore, paleoecological comparisons within the same valley may be highly informative in cultural terms. Second, the comparison proposed here may be able to unravel how low- and high-mountain forest types responded to the same climatic shifts known to have occurred during the Middle Ages. Third, it may also be possible to find eventual similarities and differences in the anthropogenic management of lower montane and highland forests. This could eventually provide clues on the cultural traits of human populations living in both environments. Fourth, the comparative analysis may also inform on eventual interactions (feedbacks, synergies) between climatic and anthropogenic drivers of change and their potential differences with forest types and elevation.

The results obtained in these particular points may also be useful to evaluate the abovementioned hypothesis of a general deforestation and anthropization of the Pyrenees during the Middle Ages to give place to modern landscapes. In addition, the information obtained may be used to infer eventual differences in the resilience of the different forest communities, which could be useful for forest conservation purposes by identifying the eventual tipping points that might lead to irreversible regime shifts. In this sense, it is important to mention that Lake Sant Maurici is within the National Park "Aigüestortes i Estany de Sant Maurici" (PNAESM), and Lake Montcortès is part of the European Natura 2000 network, two conservation entities that could benefit from the results of this study.

\section{Study area}

This study analyzes the Medieval forest dynamics at two sites that encompass the whole altitudinal range of present-day Pyrenean forests, which are formed by the same species as in the Middle Ages. Therefore, knowledge on the composition and altitudinal distribution of present forests is needed for a proper understanding of their spatial patterns and for further interpretations of past forest dynamics.

\section{Altitudinal forest zonation}

The Iberian side of the Pyrenees is characterized by a noticeable Mediterranean influence in both climatic and biogeographical patterns, especially in the central and eastern sectors. In the 
southern-central Pyreneees and their foothills, where lakes Montcortès and Sant Maurici are located, five main altitudinal stages have been distinguished. The lowlands are represented by the basal or basimontane stage, whereas the mountain stages proper include the montane, subalpine, alpine and subnival (permanent snow) stages (Fig. 2). The latter three stages (subalpine to subnival) are considered to represent the Pyrenean highlands [14]. The elevational boundaries among all these stages may show minor variations according to local bioclimatic conditions and anthropogenic influence. The average temperature lapse rate, which has been considered the main environmental driver of the altitudinal zonation of vegetation, is $-0.6^{\circ} \mathrm{C} / 100 \mathrm{~m}$ [15]. The following summary description of the main altitudinal vegetation trends, with emphasis on forests, is based on the review by Ninot et al. [16].

The submontane or basal stage is represented by Mediterranean vegetation, which reaches elevations of 800-1000 m, although it can extend up to $1300 \mathrm{~m}$ due to local particularities. Forests are dominated by evergreen Quercus rotundifolia in drier areas and marcescent $Q$. faginea, $Q$. pubescens and $Q$. subpyrenaica in milder sectors. Forests at higher elevations, such as those dominated by Pinus nigra or Pinus sylvestris, may also occur intermingled with oak forests. The montane stage is located above and reaches $1600-1800 \mathrm{~m}$ elevation. The most characteristic montane forests are dominated by Pinus sylvestris, which attains their maximum development in this stage. Patches of Fagus sylvatica may occur in moister sites, especially on calcareous soils. Intense historical anthropization of the montane stage has led to intense deforestation and the proliferation of secondary vegetation, as manifested in the occurrence of diversified scrubland, extensive grasslands and abundant reforested terrains. Gallery forests growing on river margins and lake shores are typically dominated by Corylus avellana or Alnus glutinosa, with Populus nigra, P. canadensis, Fraxinus excelsior, Salix alba, Betula pendula, Tilia platyphyllos, Acer sp., Fraxinus excelsior and Ulmus glabra.

The subalpine stage extends between the uppermost boundary of the montane stage and the treeline. The elevation of the treeline is usually $2200-2300 \mathrm{~m}$ but may also vary locally, reaching elevations of $2500 \mathrm{~m}$ in some areas. The montane-subalpine boundary defines the lower boundary of the highlands or high-mountain environments and is mainly dominated by Pinus uncinata (also known as $P$. mugo subsp. uncinata) forests with an ericaceous understory dominated by Rhododendron ferrugineum and Vaccinium myrtillus. In the lower subalpine forests, Abies may be codominant with Pinus uncinata, and some deciduous trees, such as Sorbus aucuparia, Salix capraea and Betula pubescens, may occur, especially as fast colonizers of unstable slopes or disturbed terrains. Betula pendula stands and forests are especially persistent after frequent and intense anthropogenic forest exploitation. In soils inappropriate for tree growing, such as rocky slopes and avalanche corridors, plants typical of the Pinus uncinata understory, notably Rhododendron ferrugineum, may be dominant.

The alpine stage is devoid of forests and is characterized by extensive grassland communities dominated by Festuca arioides and Carex curvula subsp. curvula in noncalcareous soils, and Kobresia myosuroides and Carex curvula subsp. rosae on calcareous terrains. Due to the abundance of microhabitats and microclimates, the alpine stage is particularly diverse in species, life forms and vegetation types and has been considered mosaic vegetation. The subnival belt extends from the treeline to the maximum elevations (slightly above $3000 \mathrm{~m}$ ). Vegetation is scarce due to harsh and changing environmental conditions. Most plants are cushion-shaped and form loose communities on favorable sites, next to the remnants of former glaciers. 
Study sites

Lake Montcortès (42 $19^{\prime} 50^{\prime \prime} \mathrm{N}-0^{\circ} 59^{\prime} 41^{\prime \prime} \mathrm{E}$; $1027 \mathrm{~m}$ elevation) is a karstic lake situated in the lowermost part of the montane belt, close to the transition with the Mediterranean submontane stage (Fig. 2). The closest weather station is situated approximately $9 \mathrm{~km}$ south and ca. 500 m elevation. The annual average temperature is $13.7^{\circ} \mathrm{C}$, ranging from $3.5^{\circ} \mathrm{C}$ in January to $24.3^{\circ} \mathrm{C}$ in July. Using the adiabatic lapse rate of $-0.6 / 100 \mathrm{~m}$, Lake Montcortès should be approximately $3{ }^{\circ} \mathrm{C}$ hotter on average. The total annual precipitation is $581 \mathrm{~mm}$, with February as the driest month $(19.4 \mathrm{~mm})$ and May as the wettest month $(66.1 \mathrm{~mm})$. Four major forest formations occur around the lake catchment, reflecting its lowland/montane boundary conditions (Fig. 3): 1) Mediterranean sclerophyllous forests of Quercus rotundifolia, 2) submontane deciduous oak forests dominated by Quercus pubescens and $Q$, subpyrenaica, 3 ) conifer forests of Pinus nigra (usually secondary replacement of the deciduous oak forests), and 4) montane forests of Pinus sylvestris, possibly including natural and planted forest stands. A detailed study of the vegetation around the lake is available, with emphasis on aquatic and semiaquatic communities [17].

Lake Sant Maurici (42 $34^{\prime} 53^{\prime \prime} \mathrm{N}-1^{\circ} 00^{\prime} 12^{\prime \prime} \mathrm{E} ; 1914 \mathrm{~m}$ elevation) is located in a former glacial cirque, now within the Pinus uncinata forest belt (Fig. 2), approximately 500-600 $\mathrm{m}$ below the treeline (Fig. 4). According to the weather station situated near the lake, the annual average temperature is $5.4{ }^{\circ} \mathrm{C}$, ranging from $-1.5^{\circ} \mathrm{C}$ (January-February) to $14{ }^{\circ} \mathrm{C}$ (July-August). The total annual precipitation is $1058 \mathrm{~mm}$, with two maxima in May $(188 \mathrm{~mm})$ and November $(110 \mathrm{~mm})$ and two minima in February $(63 \mathrm{~mm})$ and July $(65 \mathrm{~mm})$. The former glacial lake was considerably smaller and shallower than at present, but the damming of the catchment in 1953 transformed the original pond into a larger reservoir, which is used for hydroelectricity generation, irrigation and human consumption. More detailed descriptions of the sites, including geology, climate and nonforested vegetation, are available elsewhere [15,17].

\section{Methods}

The raw data for the present work were retrieved from publicly available Mendeley Data pollen databases covering the last four millennia for Lake Sant Maurici (data.mendeley.com/datasets/cdnjkyp4gz/1) and the last three millennia for Lake Montcortès

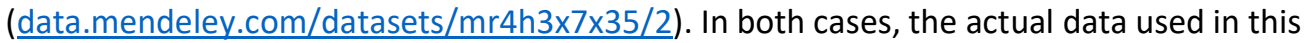
paper corresponded to the interval between $400 \mathrm{CE}$ and $1500 \mathrm{CE}$. Details on how these data were obtained may be found in refs. $[8,10,11,18,19]$. These data were reanalyzed and reorganized according to the specific aims of this study and were plotted in pollen diagrams using psimpoll 4.27 (chrono.qub.ac.uk/psimpoll/psimpoll.html). The interpretation of these pollen diagrams was based on the known ecological features of the taxa involved $[14,16,17]$ and on previous studies on modern pollen and NPP sedimentation in relation to elevation, climate and vegetation patterns $[20,21,22]$. As mentioned above, historical information was taken from ref. [2] and summarized in Appendix 1.

In the absence of local paleotemperature reconstructions for the lakes studied, comparisons were established with some nearby records. The closest paleotemperature record covering the Medieval Period is from Lake Redon, ca. 20 km WNW of Lake Sant Maurici and 2230 elevation and was obtained using diatoms as proxies [23]. Another high-elevation paleotemperature reconstruction is from Lake Gerber, ca. 5 km north of Lake Sant Maurici and 2166 m elevation, where a high-resolution record was obtained from tree rings [24]. Unfortunately, the Gerber record covers only the last 300 years of the Middle Ages (1200-1500 CE). A paleotemperature reconstruction based on isotopic analysis $\left(\delta^{13} \mathrm{C}\right)$ of speleothems from Cantabria (Fig. 1), thought to be representative of the northern Iberian Peninsula [25], was also used for 
comparison. The general paleoclimatic phases known to have occurred in continental Europe during the Middle Ages-i.e., the dark Ages Cold Period (DACP; ca. 400-850 CE), the Late Antique Little Ice Age (LALIA; ca. 540-660 CE), the Medieval Climate Anomaly (MCA; ca. 950$1250 \mathrm{CE}$ ) and the Little Ice Age (ca. 1300-1800 CE) - have been considered [26,27,28,29].

\section{Forest dynamics}

\section{Montcortès}

During the Migration Period (ca. 400-600 CE), the forests around Montcortès exhibited their maximum extension (Fig. 5). These forests were dominated by Pinus, followed by similar proportions of Quercus (both evergreen and deciduous) and other deciduous trees (Alnus, Betula, Corylus, Fagus, Salix, Ulmus). The main anthropogenic activity was cereal cultivation. The small number of spores from coprophilous fungi (Sporomiella and Sordaria) suggests lowlevel grazing activities. Charcoal influx was high and peaked at the middle of this period, indicating that burning was a common practice, probably using the slash-and-burn system, which was not abolished until the establishment of the feudal system (Appendix 1). During this period, climates were the coolest recorded during the whole Middle Ages. The whole picture suggests that, during the Migration Period, the Montcortès forests were not significantly affected by human activities, which suggests that cultivation and grazing activities were probably restricted to the likely deforested lake catchment. Indeed, previous studies on landscape anthropization demonstrated that the small lake watershed was irreversibly deforested by the Iron Age (ca. -800 BCE) [11]. The dominance of pine forests, more typical of the montane forest belt presently growing above Montcortès elevations (Fig. 2), is consistent with the occurrence of colder climates (DACP), which could have promoted a downward displacement of forest belts.

The end of the Migration Period (ca. $600 \mathrm{CE}$ ) was characterized by the general and abrupt decline of the deciduous trees, in general, but especially deciduous oaks, coinciding with increases in Pinus and evergreen oaks. Land use underwent a significant shift from cereal to Cannabis cultivation and a small increase in grazing. At the same time, fire incidence showed a significant decreasing trend, suggesting that deciduous trees would have been cut down rather than burnt. The new forests remained unchanged, although spiked by minor variations, until the Frank Empire period (ca. $830 \mathrm{CE}$ ), coinciding with a warming trend during the second half of the DACP. However, land-use indicators experienced relevant variations during this time interval. The most significant changes were the gradual decline in cereals and fire incidence, coeval with the gradual increase in wild grasses and the spectacular increase in grazing indicators. This, together with the incoming Cannabis, suggests a significant shift in the human use of lake catchments, where pastures and Cannabis crops replaced the former cereal fields. Cannabis crops underwent an important decline between ca. $770 \mathrm{CE}$ and $830 \mathrm{CE}$ (representing the late Muslim phase and the early Frank period), which coincided with the maximum grazing indicators and the onset of a gradual recovery of deciduous trees other than Quercus.

The next abrupt deforestation took place by the middle of the Frank Empire period (ca. 830 $\mathrm{CE})$. In this case, the affected trees were evergreen oaks, and the forests started to be largely dominated by Pinus. Minimum values of charcoal influx suggest that, again, these trees were cut down. It is unlikely that climate may have contributed to this forest shift, as paleotemperatures show an increasing trend, which is incompatible with a lowering of altitudinal forest belts. Cannabis crops reappeared, and wild grasses were replaced by weeds such as Artemisia and Plantago, coinciding with a dramatic decline in grazing indicators and fire incidence. This suggests that the former cereal crops of the Visigoth phase and pastures of 
the Musmlim and Frank phases disappeared and that the lake watershed was covered by Cannabis crops and abandoned lands.

The more intense deforestation of the Middle Ages began during the earlier phase of the County of Pallars (ca. $930 \mathrm{CE}$ ) and affected mostly Pinus. The abrupt Pinus decline coincided with a fire peak, which suggests that these trees were selectively burnt. From this point, evergreen Quercus started a maintained increase and became the dominant tree of the Montcortès forests. However, further Pinus recovery occurred, and its codominance was reestablished by ca. $1180 \mathrm{CE}$. The lake catchment did not experience significant changes during this time period (ca. 930-1180 CE), which was characterized by a thermal maximum corresponding to the MCA. Evergreen Quercus underwent a second clearing event by ca. 1200 $\mathrm{CE}$, associated with a small increase in fire incidence and a significant peak of grazing indicators (coprophilous fungi). This was followed by a gradual recovery that reestablished the former forest conditions by $1300 \mathrm{CE}$.

Interestingly, Olea, which was intensively cultivated in the southern Pallars lowlands since the $11^{\text {th }}$ century (Appendix 1), started to increase during the MCA, which suggests that the upper altitudinal boundary of this thermophilous tree would have migrated upwards, favored by higher temperatures. According to historical documents, the upper boundary of Olea cultivation could have reached elevations of ca. $1000 \mathrm{~m}$, where Lake Montcortès is situated (Appendix 1). The increase in Olea pollen in the Montcortès sediments was especially significant by ca. 1250 , coinciding with the decrease in Cannabis and grazing indicators. This occurred close to the beginning of the colder LIA, which may have led to a lowering of the upper boundary of olive cultivation. However, colder temperatures also favored the migration of people to the lowlands, leading to an increase in Olea cultivation. This would have contributed to the increase in Olea pollen despite the LIA colder climates due to the high upward dispersion power recorded in modern sedimentation studies [20].

During the ending Medieval crisis (ca. 1350-1480 CE), characterized by the dramatic depopulation of the Pallars region by emigration to major urban nuclei in the southern lowlands (Appendix 1), all forest trees around Montcortès recovered, although Pinus experienced selective clearing by $1400 \mathrm{CE}$, followed by further recovery. In general, the indicators of human activities (cropping, grazing, fire) showed minimal values. Olea maintained its increase, likely due to the upward high dispersion capacity of its pollen mentioned above. According to historical documents, not only climatic cooling but also other factors, such as internal wars, black pests (1348 CE) or the self-induced collapse of the feudal system, contributed to the migration of people to the lowlands (Appendix 1).

In general, the Middle Ages were characterized by a trend from high forest cover during the Visigoth phase (ca. 400 to $700 \mathrm{CE}$ ) to intense regional deforestation at the beginning of the county period (ca. $1000 \mathrm{CE}$ ) and further forest recovery until the end of the Middle Ages. Deforestation was not a general clearing phenomenon involving all forest trees at the same time but was highly selective, as the different tree taxa suffered individual and abrupt and sequential declines that produced a cumulative effect of general deforestation. The time of maximum deforestation coincided with the onset of the MCA, which suggests that warmer climates could have fostered the upward migration of people from the lowlands to the Montcortès area, leading to increased forest exploitation. The selective clearing of forest taxa strongly suggests that deforestation was anthropogenic, rather than climatic, although climate could have acted as a synergistic driver controlling human displacements toward the lake during the MCA or the southern lowlands during the LIA. 
The Medieval deforestation of Montcortès was the third recorded during the last 3000 years. The first regional forest clearing took place during the Iron Age (ca. $300 \mathrm{BCE}$ ), approximately 500 years after the irreversible anthropization of the Montcortès catchment. The second regional deforestation occurred during the Roman Period (ca. $300 \mathrm{CE}$ ). Therefore, the Montcortès area had already been anthropized, and its forests deeply transformed long before the Middle Ages and were further modified during the Modern Age by a fourth regional deforestation peaking ca. 1800 CE [11]. Further forest recovery occurred during the Industrial Revolution (1832-1935) due to the massive emigration of the Pallars population to large industrialized cities, which finished shaping current landscapes [8]. As a consequence, the idea of a general Medieval anthropization of the southern Pyrenees to shape present-day forests is not supported by this study.

\section{Sant Maurici}

The Lake Sant Maurici pollen diagram shows outstanding homogeneity. As occurs today, forests around this lake were dominated by conifers (notably Pinus) during the whole Medieval Period, except for a minor disturbance that occurred at the beginning of this phase (Fig. 6). Indeed, a gradual forest decline and a slight wild grass and weed expansion were recorded during the Migration Period, which coincided with a phase of enhanced fire incidence, suggesting slash-and-burn practices and possibly some cereal cultivation. No significant changes were recorded in trees other than Pinus, wild grasses and weeds. Coprophilous fungi were present in low amounts, suggesting low-intensity grazing. The situation is consistent with the presence of small and/or sporadic (seasonal?) human groups around the lake who locally opened clearings in the forest and practiced low-intensity agriculture. Landscape opening is supported by a small increase in Betula, which is well known for its ability to colonize highmountain forest clearings [30], and a small expansion of wild grass and weed communities. This interpretation is supported by historical documents, which highlight that itinerant slashand-burn agriculture was practiced mainly in the upper montane areas, where it provided a diversity of land uses in small areas and was adapted to the enhanced seasonality of these environments (Appendix 1).

Forest expansion began shortly after the Migration Period (ca. $600 \mathrm{CE}$ ), and the recovery was complete at the beginning of the Frank occupation of the Pallars region (ca. $810 \mathrm{CE}$ ), just after the establishment of the feudal system. Since then, no further changes have been recorded in the composition of forests and other vegetation types. Cereals almost disappeared, and coprophilous fungi experienced a small increase, suggesting a small increase in grazing activities. However, the landscape did not show signs of further anthropization. Fire incidence also declined significantly. According to historical documents (Appendix 1), itinerant slash-andburn and the associated small-scale agriculture practices disappeared with the consolidation of the feudal system, which required stricter control of the people who worked the land and where and how much they produced to properly establish and receive rent payments.

The feudal socioeconomic transformation also involved segregated land-use practices between lowlands, which were mostly dedicated to extensive crops, and highlands, which were transformed into pastures suitable for long-distance horizontal transhumance (Appendix 1). This transformation implied extensive deforestations, which determined a general lowering of the treeline to enhance the pastures and to facilitate horizontal displacements [5,7]. This is not the case for Sant Maurici highlands, where conifer forests remained during the whole Medieval Period and were not transformed into pastures, a situation that remains. In addition, San Maurici forests showed remarkable resilience, as demonstrated by their recovery after small-scale human disturbance during the Migration Period and by their outstanding stability despite the occurrence of climatic changes such as the MCA and the LIA. Therefore, the forests 
around Lake Sant Maurici also escape the idea of a general anthropization of the Pyrenees during the Middle Ages. This particular situation can be traced back to the Bronze Age, when these forests exhibited the same constancy, in both extension and taxonomic composition, as in the Middle Ages and the present [10].

The ending Medieval crisis (ca. 1350-1490 CE) also had a small impact on Sant Maurici landscapes, as manifested in a minor expansion of conifer forests, likely as a consequence of the massive migration of the Pallars population to the southern lowlands (Appendix 1). This forest expansion peaked ca. $1400 \mathrm{CE}$ and was followed by a small forest retreat coeval with the abovementioned reduction in Pinus communities around Montcortès, which may suggest the occurrence of some phenomenon of regional significance affecting the lower and higher montane environments.

\section{Regional comparisons}

Only two records are available for comparison at elevations similar to Montcortès: Estanya and Prats de Vila (Fig. 1). The main handicap is that these sites belong to different altitudinal and biogeographical regions, and their resolution for the Medieval Period (subcentennial) is significantly lower than that in Montcortès. Lake Estanya is in the southern Pyrenean lowlands at $670 \mathrm{~m}$ elevation, and the regional forests were typical of the Mediterranean lowlands, dominated by evergreen Quercus species. The Prats de Vila bog is at a similar elevation to Montcortès $(1150 \mathrm{~m})$, but the regional forests are of the Eurosiberian type, and Quercus is absent. A thorough comparison of these records with those of Lake Montcortès is available at ref. [8] and shows that, despite elevational and biogeographical differences, the general trends are similar in terms of Medieval deforestation. Indeed, major deforestation phases took place between ca. 800 and 1500 CE in Estanya [31,32] and between ca. 600 CE and 1300 CE in Prats de Vila [33]. However, differences in temporal resolution among these records during the Middle Ages prevent more detailed assessments.

High-mountain records comparable to Sant Maurici are more abundant due to the occurrence of more sedimentary archives (i.e., glacial lakes and peat bogs) at high elevations. A thorough list of these sites and a comprehensive analysis of anthropization trends are available at ref. [6]. Some of these records are from sediments of high-mountain lakes situated within the same national park as Lake Sant Maurici (PNAESM) or in the same river basin as Montcortès and Sant Maurici (Noguera Pallaresa river); these are Llebreta (1619 m), Coma de Burg (1821 m), Bassa Nera (1891 m), Redó (2116 m), Redon (2240 m) and Estanilles (2247 m) (Fig. 1). Three of these sites (Redon, Redó and Estanilles) were deforested in the Middle Ages during the Pallars County phase and under the feudal system to give place to modern landscapes. Forests around lakes Redon and Redó were cleared by ca. 950 CE and $1100 \mathrm{CE}$, respectively, for agropastoralist purposes [23]. The last deforestation recorded occurred by ca. $1400 \mathrm{CE}$ around the Estanilles peat bog, where the treeline was lowered using fire for pasture development [34]. This deforestation is coeval with forest reductions in the Montcortés and Sant Maurici records mentioned above, as suggestive of a regional event. The other three sites (Bassa Nera, Coma de Burg and Llebreta) were deforested earlier during the Bronze Age and the Iron Age $[23,35,36]$. Other highland sites of the Iberian Pyrenees beyond the PNAESM and the Noguera Pallaresa River basin seem to have been deforested and anthropized mostly during the Middle Ages, between 850 and 1100 CE [6]. These patterns were based on the chronologies provided in the original references with no further interpretations.

The resolution of all the above studies is typically centennial or subcentennial but highly variable, ranging from multidecadal to multicentennial. Therefore, it is possible that new highresolution studies of the same sites could provide more detailed and accurate deforestation 
chronologies. However, with the results presently available, the case studies of Montcortès and Sant Maurici seem to deviate from the general rule that the Pyrenees were mostly deforested during the Middle Ages to shape modern landscapes. In the case of Montcortès, the high-resolution study presented here shows that the Medieval deforestation was neither the first nor the last during the last millennia and that present-day landscapes were not shaped in the Middle Ages but after a further (Modern Age) regional deforestation and a recent forest recovery during the Industrial Revolution. In the case of Sant Maurici, the exceptionality lies in the lack of extensive deforestation and the amazing resilience of its forests during the Middle Ages (extensive to the Bronze Age). In the hypothetical framework of general Medieval Pyrenean deforestation, the Sant Maurici catchment might be considered a microrefugium [37] for high-elevation Pyrenean forests. However, more high-resolution studies at other sites are needed for a sound assessment.

\section{Conservation}

The entities involved in the conservation of the two sites studied may benefit from the longterm Medieval records shown here. In Montcortès, the main ecological driver of change during the Middle Ages was human pressure, sometimes in synergistic coupling with climatic shifts, which indirectly affected forest ecosystems by regulating upward and downward population migrations, leading to shifts in land use along the altitudinal gradient. Sociopolitical changes, notably the establishment of the feudal system, have been major drivers of land-use change, from an ancient small-scale subsistence economy to more stable and extensive land use (Appendix 1). The disappearance of the feudal regime at the end of the Middle Ages resulted in the recovery of regional forests. Therefore, forest conservation around Lake Montcortès should focus on the regulation of anthropogenic activities.

In the case of Sant Maurici, the remarkable long-term constancy of its forests has been due mainly to the absence of intense human pressure and the apparent resistance to climatic changes such as the DACP, the MCA and the LIA. In addition, these forests were resilient enough to fully recover after local and low-intensity anthropogenic disturbances occurred during the Migration Period. This means that neither climate shifts nor human pressure have been able to lead forests to a tipping point beyond which irreversible regime change may occur. The development of more long-term studies of the type presented here could be addressed to identify these thresholds of change for subalpine forests, which would be useful for conservation entities to know the maximum level disturbance (either climatic or anthropogenic) required for forest persistence. 


\section{Acknowledgments}

Lake Montcortès studies were funded by the Spanish Ministry of Science and Technology, projects REN2003-09130-C02-02 and CGL2016-7215-R and the Spanish Ministry of Economy and Competitiveness, projects CGL2012-3665 and CGL2017-85682-R. Research on Lake Sant Maurici was funded by the Autonomous Organism of National Parks, projects OAPN-387/2011 and OAPN-24505/2017.

\section{Author contributions}

Conceptualization, methodology, formal analysis, investigation, writing, VR; esources, review \& editing, project administration, funding acquisition, TVV.

\section{Conflicts of interest}

The authors declare no conflicts of interest.

\section{Data availability}

Raw data for the present study were retrieved from Mendeley Data public databases: Lake Sant Maurici (data.mendeley.com/datasets/cdnjkyp4gz/1) and Lake Montcortès

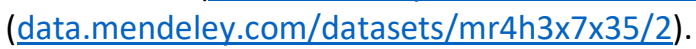




\section{References}

1. Halsall, G. 2008. Barbarian Migrations and the Roman West, 376-568. Cambridge Univ. Press, Cambridge.

2. Marugan, C.M., Oliver, J. 2005. El Pallars Medieval. In: Marugan, C.M., Rapalino, V. (Eds.), Història del Pallars. Dels Orígens als Nostres Dies. Pagès Editors, Lleida, pp. 45-86.

3. González-Sampériz, P., Aranbarri, J., Pérez-Sanz, A., et al. 2017. Environmental and climate change in the southern Central Pyrenees since the Last Glacial Maximum: a review from the lake records. Catena 149, 668-688.

4. González-Sampériz, P., Montes, L., Aranbarri, J., et al. 2019. Escenarios, tiempo e indicadores paleoambientales para la identificación del Antropoceno en el paisaje vegetal del Pirineo central (NE Iberia). Cuadernos de Investigación Geográfica 45, 167-193.

5. García-Ruiz, J.M., Tomás-Faci, G., Diarte-Blasco, P., et al. 2020. Transhumance and longterm deforestation in the subalpine belt of the central Spanish Pyrenees: an interdisciplinary approach. Catena 195, 104744.

6. Rull, V., Vegas-Vilarrúbia, T. 2021. A spatiotemporal gradient in the anthropization of Pyrenean landscapes. Preliminary report. Quaternary Science Reviews 258, 106909.

7. Gassiot, E., Mazzucco, N., Clemente, I., et al. 2017. The beginning of high mountain occupations in the Pyrenees. Human settlements and mobility from 18,000 cal BC to 2000 cal BC. In: Catalan, J., Ninot, J.M., Aniz, M. (Eds.), High Mountain Conservation in a Changing World, Springer, Cham, pp. 75-105.

8. Rull, V., Vegas-Vilarrúbia, Corella, J.P., et al. 2021b. A unique Pyrenean varved record provides a detailed reconstruction of Mediterranean vegetation and land use dynamics over the last three millennia. Quaternary Science Reviews 268, 107128.

9. Gassiot, E. 2016. Montañas Humanizadas. Arqueología del Passtoralismo en el Parque nacional d'Aigüestortes i Estany de Sant Maurici. Organismo Autónomo de Parques Nacionales, Madrid.

10. Rull, V., Cañellas-Boltà, N., Vegas-Vilarrrúbia, T. 2021a. Late-Holocene forest resilience in the central Pyrenean highlands as deduced from pollen analysis of Lake Sant Maurici sediments. Holocene, doi 10.1177/09596836211033207.

11. Rull, V., Vegas-Vilarrúbia, T., Corella, J.P., et al. 2021c. Bronze Age to Medieval vegetation dynamics and landscape anthropization in the southern-central Pyrenees. Palaeogeography, Palaeoclimatology, Palaeoecology 571, 110392.

12. Marugan, C.M., Rapalino, V. 2005. Història del Pallars. Dels Orígens als Nostres Dies. Pagès Editors, Lleida. See also the abridged English translation by Rull (2021).

13. Rull, V. 2021. Cultural development of the Pallars region (NE Iberian Peninsula) from the Bronze Age to the present. PaleorXiv, doi 10.31233/osf.io/kb95m.

14. Vigo, J. 2008. Flora i Vegetació de l'Alta Muntanya Catalana. Institut d'Estudis Catalans, Barcelona.

15. Carrillo, E., Aniz, M. 2013. Guía del Parque Nacional de Aigüestortes i Estany de Sant Maurici. Organismo Autónomo de Parques Nacionales, Madrid.

16. Ninot, Carrillo, E., Ferré, A. 2017. The Pyrenees. In: Loidi, J. Eds.), The Vegetation of the Iberian Peninsula. Springer Nature, Cham, pp. 323-366.

17. Mercadé, A., Vigo, J., Rull, V., et al. 2013. Vegetation and landscape around Lake Montcortès (Catalan pre-Pyrenees) as a tool for palaeoecological studies of lake sediments. Colectanea Botanica 32, 87-101.

18. Rull, V., González-Sampériz, P., Corella, J.P., et al. 2011. Vegetation changes in the southern Pyrenean flank during the last millennium in relation to climate and human activities: the Montcortès lacustrine record. Journal of Paleolimnology 46, 387-404.

19. Montoya, E., Rull, V., Vegas-Vilarrúbia, T., et al. 2018. Grazing activities in the southern central Pyrenees during the last millennium as deduced from the non-pollen 
palynomorphs (NPP) record of Lake Montcortès. Review of Palaeobotany and Palynology 254, 8-19.

20. Cañellas-Boltà, N., Rull, V., Vigo, J., et al. 2009. Modern pollen-vegetation relationships along an altitudinal transect in the central Pyrenees (south-western Europe). Holocene 19, $1185-1200$.

21. López-Vila, J., Montoya, E., Cañellas-Boltà, N., et al., 2014. Modern non-pollen palymomorphs sedimentation along an elevational gradient in the southern-central Pyrenees (southwestern Europe) as a tool for Holocenepaleoecological reconstruction. Holocene 24, 1757-1770.

22. Rull, V., Trapote, M.C., Safont, E., et al. 2017. Seasonal patterns of pollen sedimentation in Lake Montcortès (Central Pyrenees) and potential applications to high-resolution paleoecology: a 2-year pilot study. Journal of Paleolimnology 57, 96-108.

23. Catalan, J., Pèlachs, A., Gassiot, E., et al. 2013. Interacción entre clima y ocupación humana en la configuración del paisaje vegetal en el Parque nacional de Aigüestortes i Estany de Sant Maurici a lo largo de los últimos 15.000 años. Proyectos de Investigación en Parques Nacionales: 2009-2012. Organismo Autónomo de Parques Nacionales, Madrid, pp. 71-92.

24. Büntgen, U., Krusic, P.J., Verstege, A., et al. 2017. New tree-ring evidence from the Pyrenees reveals western Mediterranean climate variability since Medieval times. Journal of Climate 30, 5295-5318.

25. Martín-Chivelet, J., Muñoz-García, M.B., Edwards, R.L., et al. 2011. Land surface temperature changes in Northern Iberia since $4000 \mathrm{yr} B P$, based on $\delta^{13} \mathrm{C}$ of speleothems. Global and Planetary Change 77, 1-12.

26. Gribbin, J., Lamb, H.H. 1978. Climatic change in historical times. In: Gribbin, J. (ed.), Climatic Change. Cambridge University Press, Cambridge, pp. 68-82.

27. Mann, M.E., Zhang, Z., Rutherford, S., et al. 2009. Global signatures and dynamic origins of the Little Ice Age and the Medieval Climate Anomaly. Science 326, 1256-1260.

28. Büntgen, U., Myglan, V.S., Charpentier, F., et al. 2016. Cooling and societal change during the Late Antique Little Ice Age from 536 to around 660 AD. Nature Geoscience 9, 231-236.

29. Helama, S., Jones, P.D., Briffa, K.R. 2017. Dark Ages Cold Period: a literature review and directions for future research. Holocene 27, 1600-1606.

30. Dubois, H., Verkasalo, E., Claessens, H. 2020. Potential of Birch (Betula pendula Roth and B. pubescens Ehrh.) for forestry and forest-based industry sector within the changing climate and socio-economic context of Western Europe. Forests 11, 336.

31. Riera, S., Wansard, G., Julià, R. 2004. 2000-year environmental history of a karstic lake in the Mediterranean Pre-Pyrenees: the Estanya lake (Spain). Catena 55, 293-324.

32. Riera, S., López-Sáez, J.A., Julià, R. 2006. Lake responses to historical land use changes in northern Spain: The contribution of non-pollen palynomorphs in a multiproxy study. Review of Palaeobotany and Palynology 141, 127-137.

33. Pèlachs, A., Pérez-Obiol, R., Ninyerola, M., et al. 2009. Landscape dynamics of Abies and Fagus in the southern Pyrenees during the last 2200 years as a result of anthropogenic impacts. Review of Palaeobotany and Palynology 156, 337-349.

34. Cunill, R., Soriano, J.N., Bal, M.C., et al. 2013. Holocene high-altitude vegetation dynamics in the Pyrenees: a pedoanthracology contribution to an interdisciplinary approach. Quaternary International 289, 60-70.

35. Garcés-Pastor, S., Cañellas-Boltà, N., Pèlachs, A., et al. 2017. Environmental history and vegetation dynamics in response to climate variations and human pressure during the Holocene in Bassa Nera, Central Pyrenees. Palaeogeography, Palaeoclimatology, Palaeoecology 479, 48-60.

36. Pèlachs, A., Soriano, J.M., Nadal, J., et al. 2007. Holocene environmental history and human impact in the Pyrenees. Contributions to Science 3, 421-429.

37. Rull, V. 2008. Microrefugia. Journal of Biogeography 36, 481-484. 


\section{Appendix 1: Medieval history and culture of the Pallars region}

This Appendix outlines the main political and cultural developments of the Pallars region, where lakes Montcortès and Sant Maurici are located, according to ref. [2]. Pallars is a historical region whose full political and geographical identity was attained during the Middle Ages as the independent County of Pallars (872 CE to $1488 \mathrm{CE}$ ), which roughly coincided with the assemblage of the three present-day Catalan political subdivisions (comarques) of Pallars Jussà, Pallars Sobirà and Alta Ribagorça.

After the disappearance of the Roman Empire, during the so-called Migration Period, the Visigoths consolidated their dominion in southern Gallia (roughly the present France) with the foundation, in $418 \mathrm{CE}$, of the Reign of Tolosa (now Toulouse), north of the Pyrenees, and then expanded to the south. The presence of Visigoths in the Pallars region is poorly documented, and those times (418-711 CE) were considered a dark period before the establishment of the feudal system. It has been suggested that the disappearance of the Roman Empire led to the reinforcement of local autochthonous (Iberian) societies. The Muslim invasion of the Pyrenees arrived from the south by $711 \mathrm{CE}$. The Pallars region was in the northern boundary of the Muslim Empire and was populated by a diversity of cultures, including Iberians, Romans and Muslims, among others. No significant socioeconomic changes occurred until the arrival of the Carolingians at the beginning of the $9^{\text {th }}$ century.

The Frank Empire (also known as the Carolingian Empire) conquered Tolosa in 507 CE and expanded to the southern side of the Pyrenees, where they occupied the Pallars region by 800 $\mathrm{CE}$ and incorporated this region into the so-called Hispanic Marches, a buffer territory created to serve as protection against possible Muslim invasions from the south. At the beginning, the Pallars was controlled by the Counts of Tolosa, belonging to the Frank Empire, but in $872 \mathrm{CE}$, the Pallars separated from Tolosa and, hence, from the Carolingian Empire to become the independent County of Pallars. This situation remained for approximately six centuries until, in 1488 , the region was conquered by the Catalan-Aragonese Crown, formed by the dynastic union of the Kingdom of Aragón and the Principality of Catalonia. In this way, the former County of Pallars was incorporated into the Catalan-Aragonese Crown as a Marquisate under the lead of the Dukes of Cardona.

In the Pallars region, the feudal system initiated its development during the $9^{\text {th }}$ century, under Carolingian occupation, and was consolidated in the $11^{\text {th }}$ century during the governance of the Counts of Pallars. These counts were the owners of the largest part of the land and, hence, the more powerful feudal lords, followed by the other nobles and knights at the service of the Counts of Pallars, who owned the terrains around their castles, and the Catholic church, which was organized into parishes and their corresponding lands. However, a special condition in the Pallars region was the local survival of families of farmers ruling their own lands, grouped in small villages, frequently with common goods that were administered collectively. The Medieval Pallars was fundamentally rural, without important cities, the main habitation places were isolated houses and their associated terrains, and small villages typically developed around or close to churches.

The working lands were preferably crop fields, meadows and pastures, which were easier to control by the feudal system in terms of rent collection than other less stable terrains such as wetlands, river margins or forests. The itinerant slash-and-burn agriculture was practiced mainly in the montane areas, where it provided a diversity of land uses in small areas and was adapted to the enhanced seasonality of these environments. However, these practices disappeared with the consolidation of the feudal system, which required strict control of the people who worked the land and where and how much they produced, to properly establish 
and receive rent payments. Therefore, the introduction of the feudal system represented the end of the ancient small-scale subsistence economy and the beginning of more stable and extensive land use.

The main crops were cereals, olive and grapevines, which have been considered the three more traditional Mediterranean crops. The nutrient depletion produced by intensive cereal cultivation was compensated by a system of crop rotation using legumes. The use of manure of animal origin was not documented until the $12^{\text {th }}$ century and was possibly restricted to barley crops, which were the most demanding. Extensive olive tree cultivation has been documented in the Pallars since the 11th century, especially in the southern lowlands, where the climate is more appropriate for this tree, whose northern boundary seems to have been situated near Lake Montcortès. The northern mountain valleys, where Lake Sant Maurici is located, were more appropriate for pastures. The introduction of vine cultivation in the Pallars region has been considered the continuation of a Roman tradition, possibly favored by mid-Medieval climatic warming. The first vineyards were documented in the 9th century around the first churches and monasteries as marginal crops for local consumption. After feudal consolidation, the vineyards became more extensive, and viticulture was a programmed crop subjected to rent payments, which reached montane areas at elevations above $1000 \mathrm{~m}$.

A major innovation of the Middle Ages was the development of herding practices involving long-distance or horizontal transhumance. Vertical transhumance was practiced from antiquity (possibly the Bronze Age) and was the main type of livestock movement performed until the $9^{\text {th }}$ century in the Pallars region. Vertical transhumance implied the seasonal short-distance migration of livestock herds (mainly sheep flocks) and the people responsible for them between summer (highlands) and winter (lower valleys) pastures and was mainly performed on mountain regions by small landowners. In contrast, horizontal transhumance involved the long-distance displacement of livestock across large regions, which required a different social organization and a more specialized herding system. The monasteries were the first to develop long-distance transhumance, and other laic feudal owners incorporated this practice in the $10^{\text {th }}$ century. However, smaller individual owners did not disappear, thus contributing to a diversity of pastoralism and transhumant practices.

At the end of the Medieval Period (between 1350 CE and 1487 CE), the Pallars region underwent significant depopulation by the emigration of people to major urban nuclei in the southern lowlands. This led to a general impoverishment and a deep territorial restructuration characterized by a permanent struggle for the occupancy of abandoned crops, pastures and forests. This population crisis has been considered to be the result of several factors, including (i) French invasions from the north; (ii) the black plague that peaked locally in $1348 \mathrm{CE}$; (iii) the prolonged Pallars war, which ended with the abovementioned conquest by the CatalanAragonese Crown; (iv) LIA climatic cooling; and (v) the unsustainability of the feudal system, which would have led to a self-induced collapse. 


\section{Figure captions}

Figure 1. Location map. A) Topographic map of the Iberian Peninsula indicating the location of the study area (white box) in the Pyrenean range. The black dot is the approximate location of the Cantabrian Range where speleothem paleotemperature records were obtained (see methods). B) Topographic map of the study area indicating the position of the lakes analyzed in this paper (red dots) and other sites used for comparison (blue dots). Lowlands are in green; highlands in brown, and intermediate elevations are in yellow. B, Bassa Nera (bog); C, Coma de Burg (paleolake); E, Estanya (lake); Et, Estanilles (bog); L, Llebreta (lake); M, Montcortès (lake); P, Prats de Vila (bog); R, Redó (lake); Rd, Redon (lake); S, Sant Maurici (lake).

Figure 2. Altitudinal zonation of the southern-central Pyrenees showing the elevational arrangement of the dominant forest types. The locations of lakes Montcortès (M) and Sant Maurici (S) are indicated by red dots. Modified from refs. [14] and [16].

Figure 3. Vegetation around Lake Montcortès in the transition between the submontane and the lower mountain belts. A) View of the lake surrounded by stands of marcescent Quercus pubescens/Q. subpyrenaica and some evergreen $Q$. rotundifolia. The evergreen forests in the background are Pinus nigra (also known as Pinus nigra ssp salzmanii) and $P$. sylvestris. B) General view of the vegetation around Montcortès, showing the transition between the marcescent submontane oak forests (orange) and the evergreen montane pine forests (dark green). Photos: V. Rull.

Figure 4. Vegetation around Lake Sant Maurici. A) The lake is totally surrounded by Pinus uncinata subalpine forests. Some parts of the dam are visible at the distal end of the lake. B) The same forests dominate the landscape of the subalpine stage until the treeline (white lines) is situated between approximately 2300 and $2500 \mathrm{~m}$ elevation. The highest peaks around the lake attain elevations of ca. $2800 \mathrm{~m}$. Photos: V. Rull.

Figure 5. Summary pollen diagram of the Lake Montcortès sedimentary sequence corresponding to the Middle Ages using the main elements from forests, meadows and cultivated plants, as well as other relevant indicators of human activities (coprophilous fungi and charcoal, as proxies for grazing and fire incidence, respectively). The category "other deciduous trees" includes Alnus, Betula, Corylus, Fagus, Salix and Ulmus. Coprophilous fungi include Sporormiella and Sordaria. AP, Arboreal pollen; NAP, Non-Arboreal Pollen. All taxa are given as percentages with respect to the pollen sum, except charcoal particles, which are expressed in influx units (particles $\mathrm{cm}^{-2} \mathrm{y}^{-1}$ ). Paleotemperature curves from Lake Redon [23] and speleothems from Cantabria caves [25] are also represented for comparison (SFTA, summer-fall temperature anomaly; RT, relative temperatures). Red arrows mark deforestation events, and blue arrows mark forest recovery trends. Abbreviations of historical phases: $\mathrm{FE}$, Frank (or Carolingian) Empire; ME, Muslim Empire; MP, Migration Period; EMC, Ending Medieval Crisis. Abbreviations of climatic phases: DACP, Dark Ages Cold Period; LALIA, Late Antique Little Ice Age; LIA, Little Ice Age; MCA, Medieval Climate Anomaly.

Figure 6. Summary pollen diagram of the Lake Sant Maurici sedimentary sequence corresponding to the Middle Ages using the main elements from forests, meadows and cultivated plants, as well as other relevant indicators of human activities (coprophilous fungi and charcoal, as proxies for grazing and fire incidence, respectively). Conifers include mainly Pinus, with a small amount of Abies. Ericaceae are included in the forest category, as this pollen type is difficult to identify in the shrubby understory of subalpine pine forests, dominated by Rhododendron and Vaccinium (see the vegetation description). The category "other deciduous trees" includes Alnus, Corylus, Fagus, Fraxinus, Salix and Ulmus. Weeds 
include Artemisia, Chenopodium, Plantago and Rumex. Coprophilous fungi include Sporormiella and Sordaria. AP, Arboreal pollen; NAP, Non-Arboreal Pollen. All taxa are given as percentages with respect to the pollen sum, except charcoal particles, which are expressed in influx units (particles $\mathrm{cm}^{-2} \mathrm{y}^{-1}$ ). Paleotemperature curves from Lake Redon [23] and speleothems from Cantabria caves [25] are also represented for comparison (SFTA, summerfall temperature anomaly; RT, relative temperatures). Red arrows indicate deforestation trends, and blue arrows indicate forest recovery trends. Abbreviations of historical phases: $\mathrm{FE}$, Frank (or Carolingian) Empire; ME, Muslim Empire; MP, Migration Period; EMC, Ending Medieval Crisis. Abbreviations of climatic phases: DACP, Dark Ages Cold Period; LALIA, Late Antique Little Ice Age; LIA, Little Ice Age; MCA, Medieval Climate Anomaly. 


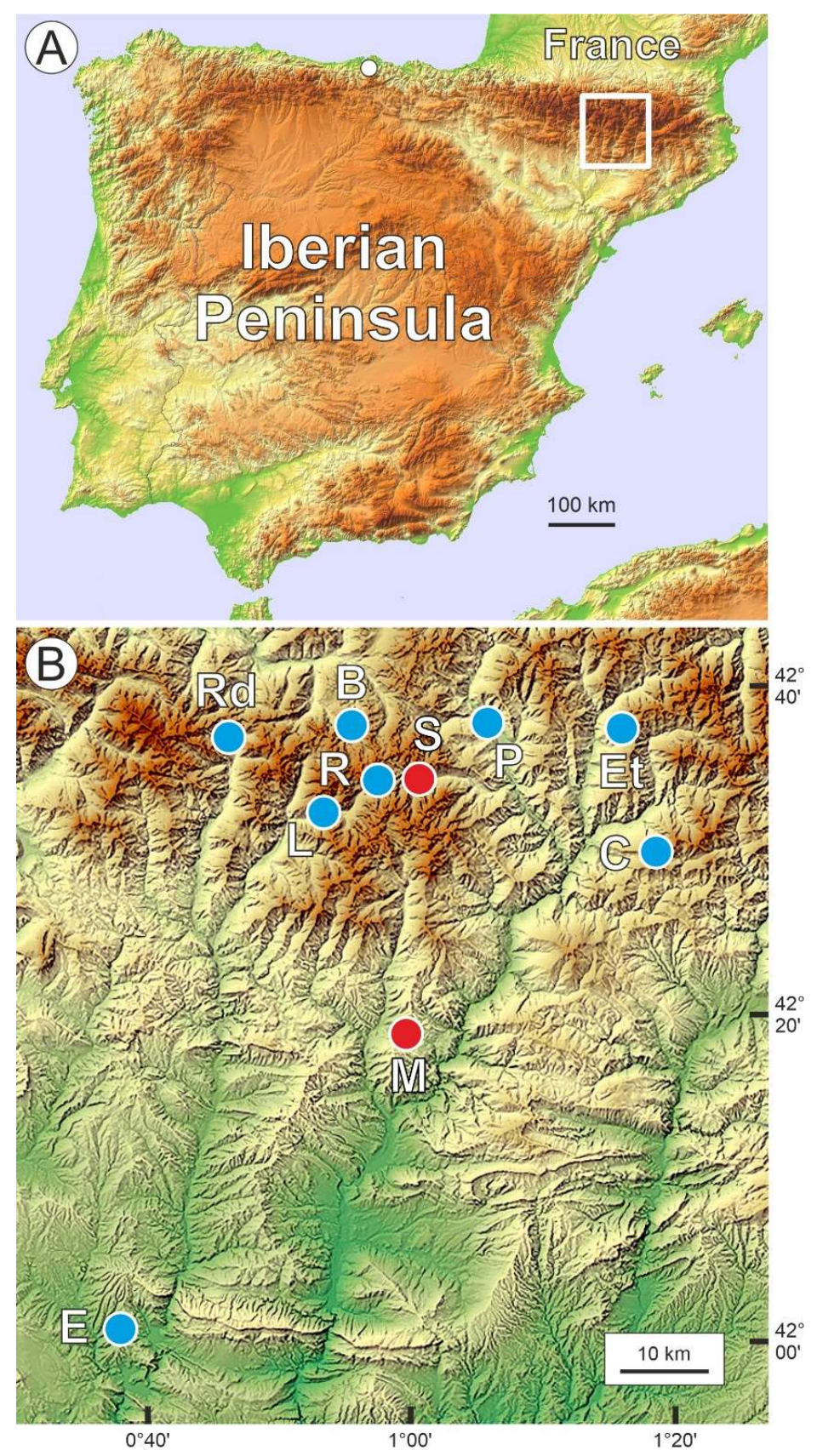

Figure 1 


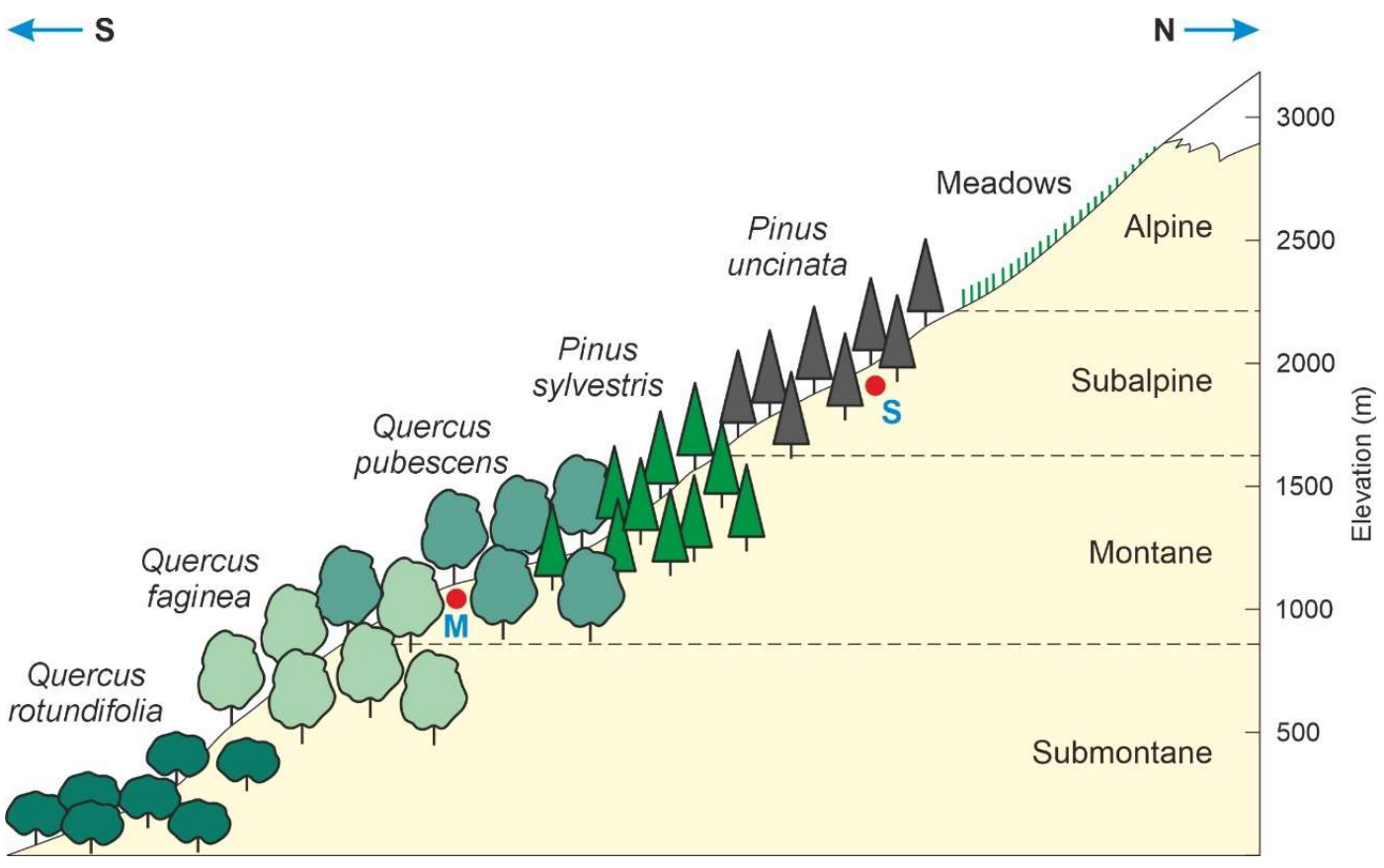

Figure 2 

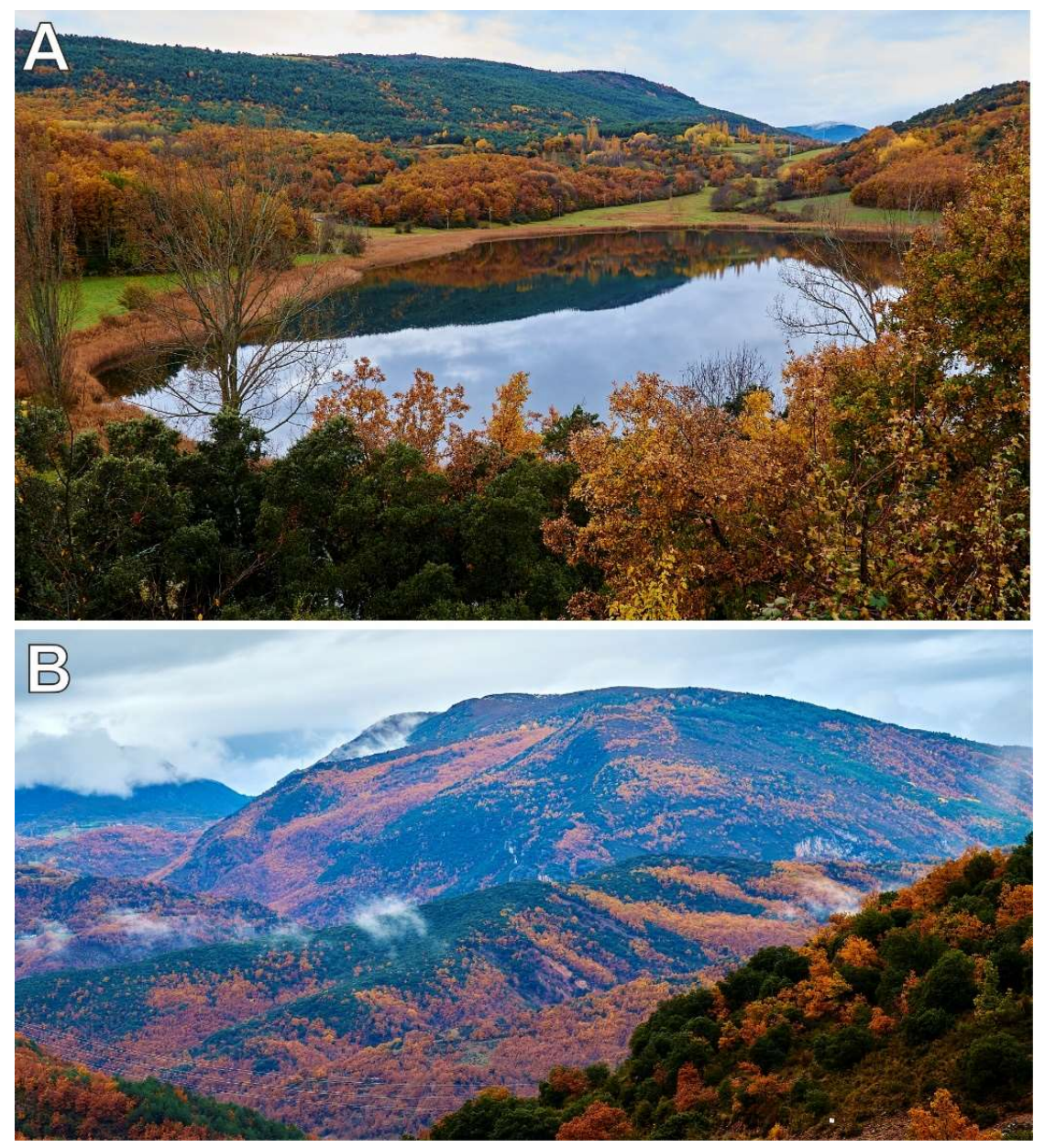

Figure 3 


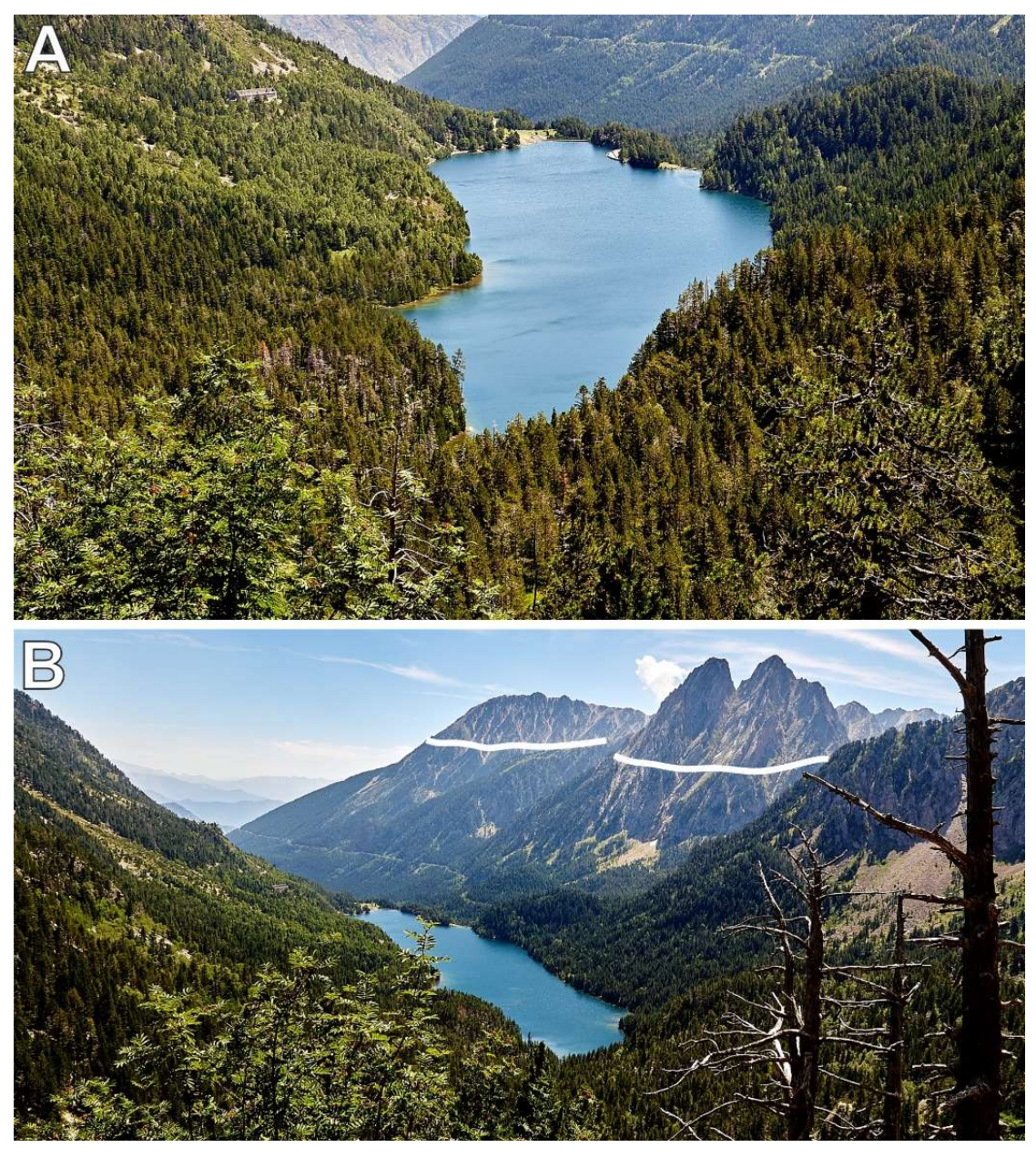

Figure 4 

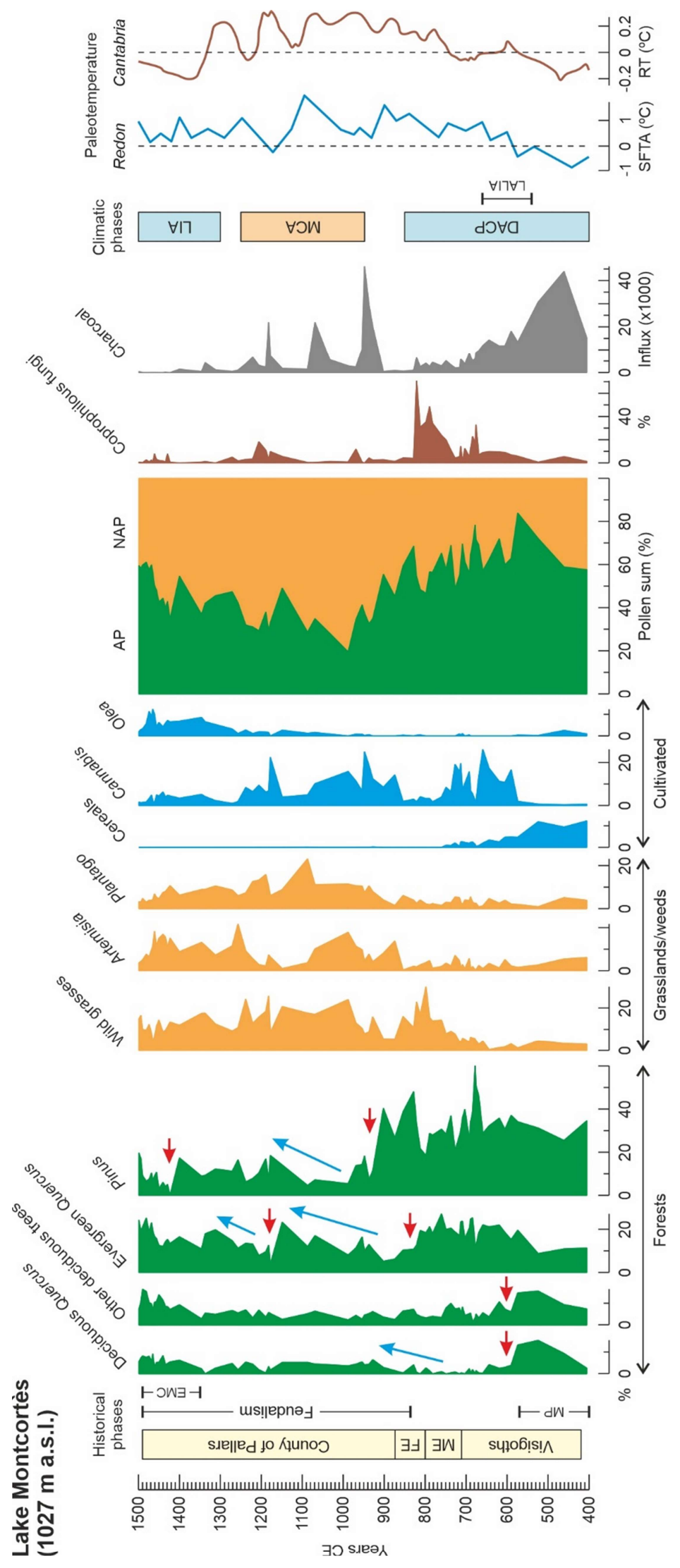

Figure 5 

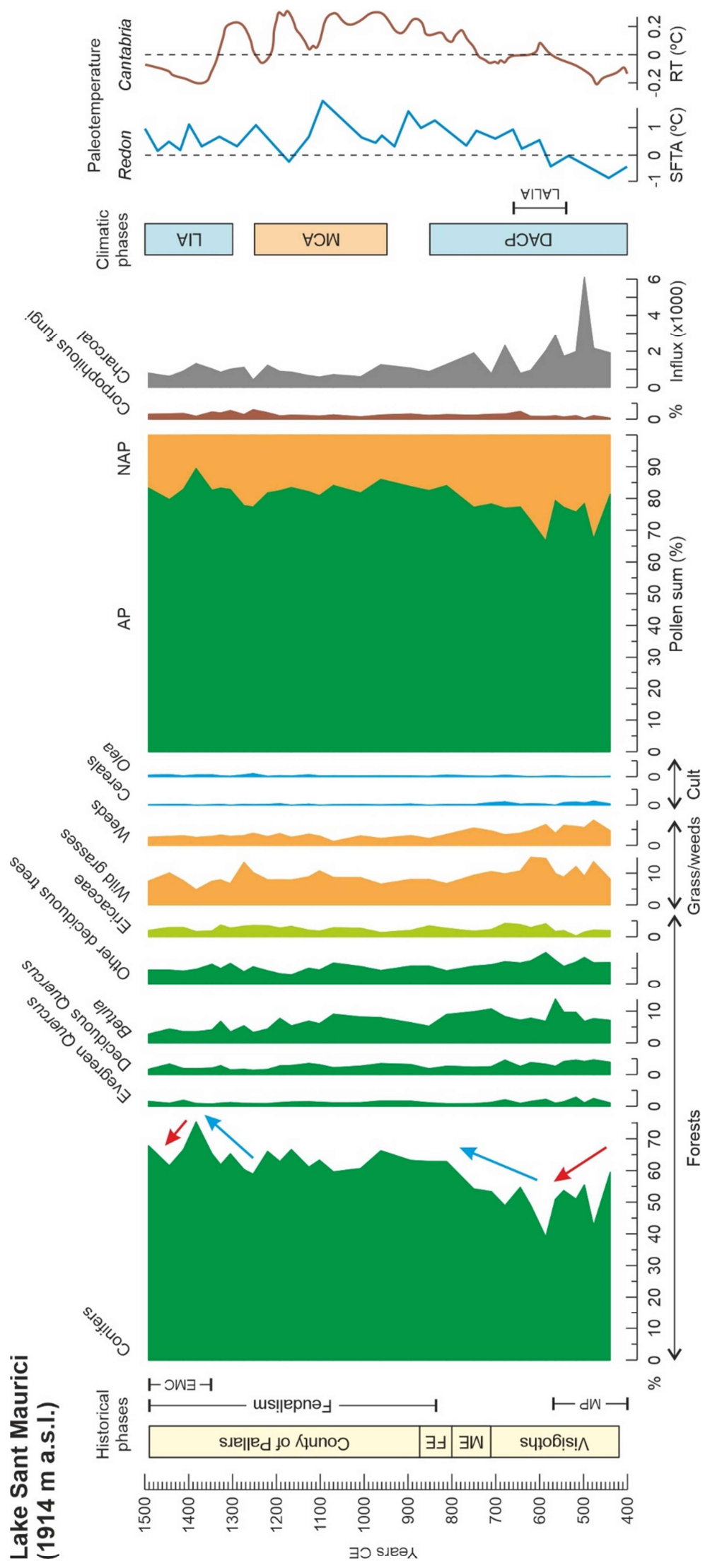

Figure 6 
